\title{
URGENSI MADRASAH DI ERA KONTEMPORER
}

\author{
H. Anwar Rasjid \\ (Dosen Fak. Tarbiyah IAIN Sunan Ampel)
}

\begin{abstract}
Abstrak
Tulisan ini bermaksud megulas eksitensi madrasah di era kontemporer. Sebagai lembaga pendidikan yang sudah lama berkembang di Indonesia, madrasah selain telah berhasil membina dan mengembangkan kehidupan moral dan beragama di Indonesia, juga ikut serta berperan dalam menanamkan rasa kebangsaan ke dalam jiwa rakyat Indonesia, di samping itu Madrasah juga berperan dalam mencerdaskan kehidupan bangsa. Meski demikian performa madrasah saat ini masih dirasakan berkualitas kurang dan sangat perlu untuk ditumbuh-kembangkan pada masa yang akan datang. Masyarakat di era sekarang (kontemporer) semakin menjadikan madrasah sebagai lembaga pendidikan yang unik. Di saat ilmu pengetahuan dan teknologi berkembang pesat, di saat filsafat hidup manusia modern mengalami krisis moral dan keagamaan, dan di saat perdagangan bebas dunia makin mendekati pintu gerbangnya, keberadaan madrasah tampak makin dibutuhkan orang. Hal ini menunjukkan urgensi dan signifikansi eksistensi madrasah di era kontemporer.
\end{abstract}

Kata Kunci: Madrasah dan Era Kontemporer 


\section{A. Pendahuluan}

Kelembagaan madrasah merupakan formalisasi yang dilakukan pemerintah terhadap sistem pendidikan informal yang telah ada sebelumnya, sisi lain karena adanya ketentuan-ketentuan yang lebih jelas yang berkaitan dengan komponen-komponen pendidikan dan keterlibatan pemerintah dalam pengelolaan pendidikan keagamaan Islam. Oleh karena itu keberadaan madrasah pada waktu itu merupakan tonggak baru dalam penyelenggaraan pendidikan Islam yang banyak memberikan kontribusi terhadap perkembangan dunia pendidikan pada masa-masa berikutnya, termasuk perkembangan pendidikan di dunia Barat.

Madrasah merupakan fenomena modern yang dimulai sekitar awal abad ke-20 M. Tidak ada kejelasan hubungan madrasah abad ke 11$12 \mathrm{M}$. di Timur Tengah dengan munculnya madrasah di Indonesia pada awal abad ke-20 M. Sejarah pertumbuhan madrasah di Indonesia, jika dikembalikan pada situasi awal abad ke-20 M, dianggap memiliki latar belakang sejarahnya sendiri, walaupun sangat dimungkinkan ia merupakan konsekuensi dari pengaruh intensif pembaharuan pendidikan Islam di Timur Tengah masa modern. Karel Steenbrink mengindikasikan bahwa pendidikan Islam berevolusi dari pesantren, madrasah dan kemudian sekolah, sebab itu madrasah di Indonesia dianggap sebagai perkembangan lanjut dari pendidikan pesantren dan surau. ${ }^{1}$

Eksistensi madrasah seperti sekarang ini merupakan akumulasi berbagai macam budaya dan tradisi pendidikan yang berkembang di Indonesia. Mulai dari tradisi pra-sejarah atau tradisi asli, tradisi HinduBudha, tradisi Islam, dan tradisi Barat atau modern. ${ }^{2}$ Madrasah telah menjadi salah satu wujud entitas budaya bangsa Indonesia yang telah menjalani proses sosialisasi yang relatif intensif, dan dalam waktu yang cukup panjang itu telah memainkan peran tersendiri dalam panggung pembentukan peradaban bangsa.

\footnotetext{
${ }^{1}$ Karel Steenbrink, Pesantren, Madrasah dan Sekolah (Jakarta: LP3ES, 1994).

${ }^{2}$ Malik Fadjar, Madrasah dan Tantangan Modernitas (Bandung: Mizan, 1998), 19.
} 


\section{B. Memahami Madrasah}

Kata madrasah berasal dari bahasa Arab, diambil dari akar kata darasa yang berarti belajar. Madrasah adalah isim makan dari kata darasa sehingga memiliki arti tempat untuk belajar. Istilah madrasah sering diidentikkan dengan istilah sekolah atau semacam bentuk perguruan yang dijalankan oleh sekelompok atau institusi umat Islam. Secara umum madrasah juga sama dengan sekolah-sekolah lain, yaitu lembaga pendidikan yang menggunakan sistem klasikal dan kelas dengan segala fasilitasnya, seperti: kursi, meja dan papan tulis, kecuali aspek tradisi dan kurikulum yang dilaksanakan.

Meskipun sekarang posisi madrasah secara yuridis sama dengan sekolah terutama dalam aspek kurikulum, ${ }^{3}$ tetapi madrasah secara umum masih mempertahankan ciri khasnya sebagai sekolah yang berciri khas Islam. Madrasah sebagai salah satu bentuk kelembagaan pendidikan Islam memiliki sejarah yang sangat panjang. Munculnya pendidikan madrasah pada awalnya selain dilatarbelakangi oleh motivasi agama dan motivasi ekonomi, juga motivasi politik.

Pada saat sebelum terbentuk sistem madrasah, pada awalnya proses pendidikan dan pengajaran dilaksanakan di masjid/surau/musholla dan pesantren. Setelah terbuka dan semakin kuatnya proses pembentukan intellectual webs (jaringan intelektual) di kalangan umat Islam dengan Haramain sebagai sumber tempat yang asli, nuansa mistik yang kental di pondok pesantren lambat laun semakin berkurang dan bergerak ke arah proses ortodoksi, atau oleh pengamat peradaban di Indonesia menyebut adanya proses bergerak dari Islam yang bercorak mistik menuju ke Islam Sunni. ${ }^{4}$

Di sisi lain juga terjadi proses perubahan isi pembelajaran di dalam format-format pembelajaranya. Persentuan global dengan pusat Islam di Haramain memungkinkan para pelaku pendidikan Islam melihat sistem pembelajaran yang lebih terprogram. Sehingga tumbuh dan berkembanglah pola pembelajaran materi pelajaran Islam yang dikelola dengan sistem Madrasi. Sebagaimana dimaklumi bahwa sistem madrasah pertama kali didirikan dan diperkenalkan di dunia Islam adalah madrasah

\footnotetext{
${ }^{3}$ Permendiknas No. 22, 23, 24 Tahun 2006.

${ }^{4}$ Malik Fadjar, Madrasah ..., 22. 
Nizamiyah di Baghdad yang didirikan oleh perdana mentri Nizamul Mulk (1018/1019-1092), seorang penguasa Bani saljuk pada abad II yang salah seorang gurunya adalah Imam Ghazali. ${ }^{5}$

Setelah itu, sistem madrasah ini berkembang ke berbagai kota di negeri Islam, antara lain di Kairo (Mesir) berdiri perguruan al-Azhar, di Spanyol berdiri perguruan Cordoba dan di India berdiri madrasah Deoban. Dari sini dapat diketahui bahwa madrasah yang ditemukan di Indonesia bukanlah suatu lembaga yang indigenius (pribumi) dalam peta dunia pendidikan di Indonesia, dan juga sebagaimana yang ditunjukkan oleh kata madrasah itu sendiri yang berasal dari bahasa Arab. Secara harfiah kata madrasah setara maknanya dengan sekolah. Berbeda dengan pesantren, yang oleh para peneliti/ilmuwan dipandang sebagai lembaga pendidikan Islam yang memiliki watak indigenous (asli pribumi Indonesia). ${ }^{6}$

Dari aspek pengelolaan, pendidikan di madrasah ini memungkinkan cara pembelajaran secara klasikal. Hal ini berbeda dengan cara yang berkembang di pondok pesantren yang lebih bersifat individual seperti yang terdapat pada sistem sorogan dan wetonan. Pengelolaan sistem madrasi juga memungkinkan adanya pengelompokan materi pelajaran tentang pengetahuan Islam yang penyampaiannya dilakukan secara bertingkat-tingkat. Pengelompokan ini sekaligus memperhitungkan rentang waktu yang dubutuhkan.

Secara teknis, sistem madrasi berusaha mengorganisasikan kegiatan kependidikannya dengan sistem kelas-kelas berjenjang dengan waktu yang diperlukan untuk menyelesaikan pelajaran yang sudah dipolakan. ${ }^{7}$ Keberadaan madrasah dari waktu ke waktu semakin jelas sosoknya, sementara visi keislaman terus mengalami perubahan, seiring dengan semakin kuatnya kontak dengan dunia luar terutama dengan negara-negara Islam dan juga dipengaruhi oleh kolonialisasi di nusantara ini yang berabad-abad lamanya.

Madrasah sampai saat ini masih menjadi lembaga pendidikan yang eksis. Eksistensi Madrasah berbarengan dengan semakin

${ }^{5}$ Ensiklopedi Islam - 2 Fas-kal (Jakarta: PT. Ichtiar Baru Van Hoeve, 1993), 3.

${ }^{6}$ Malik Fadjar, Madrasah..., 20.

${ }^{7}$ M. Asrori Ardiansyah, dalam www.kabar-pendidikan.blogspot.com, diunduh pada 18 Desember 2012. 
meningkatnya mutu lulusan yang tidak kalah dengan lembaga pendidikan lainnya dalam konstalasi sistem pendidikan nasional. Meningkatnya mutu madrasah tentu bukan dihasilkan dari proses instan, kebanggan rasa memilki (sense of belonging), jiwa altruistic (tulus ikhlas) dalam bekerja dan semangat fastabiq al-khoiraat (berlomba dalam kebaikan) adalah bagian penting mengapa madrasah tetap kokoh dalam pusaran kemajuan zaman dengan segenap implikasinya.

\section{Madrasah dalam Sejarah}

Madrasah di Indonesia telah ada sejak awal abad ke-20 M, atau paling cepat pada akhir abad ke-19 M, bersamaan dengan munculnya Ormas Islam, seperti NU dan Muhammadiyah. ${ }^{8}$ Dalam catatan historis, keberadaan pendidikan Islam formal, ditandai dengan munculnya madrasah sebagai lembaga dan jalur pendidikan. Sebagaimana sekolah pada umumnya, di dalam madrasah berlangsung proses komunikasi pedagogis antara guru dan siswa dalam rangka mencapai tujuan yang telah ditentukan. ${ }^{9}$ Secara historis pula, kelahiran madrasah menjadi lambang kebangkitan sistem pendidikan Islam. ${ }^{10}$

Berbeda dengan kondisi sekolah umum, madrasah mengalami sejumlah persoalan, diantaranya rendahnya sumber daya kependidikan. Hal ini dapat dilihat dari rendahnya kualitas guru, rendahnya kemampuan manajerial kepala madrasah dan birokrasi pada Kementerian Agama, terlihat dari kurangnya sumber daya yang bisa menentukan kebijakan, perencanaan dan manajemen. ${ }^{11}$ Meskipun demikian, keberadaannya tetap menjadi penting dan sangat berperan dalam ikut mencerdaskan generasi bangsa. Kebanyakan madrasah dikelola secara mandiri oleh sebuah yayasan dan tidak begitu menggantungkan diri pada subsidi pemerintah.

Madrasah berdiri atas inisiatif dan realisasi dari pembaharuan Islam yang telah ada, yakni antara pengaruh pembaharuan Islam di Timur

\footnotetext{
${ }^{8}$ Abd. Rachman Assegaf, Internasionalisasi Pendidikan (Yogyakarta: Gama Media, 2003), 287.

${ }^{9}$ Ramayulis, Ilmu Pendidikan Islam (Jakarta: Kalam Mulia, 1994), 158.

${ }^{10}$ Abdullah Idi dan Toto Suharto, Revitaslisasi Pendidikan Islam (Yogyakarta: Tiara Wacana, 2006), 20.

${ }^{11}$ Tim UIN Suka, Bunga Rampai Pendidikan Islam, Analisis Kebijakan Pendidikan Guru Madrasah Ibtidaiyah (Yogyakarta: UIN Sunan Kalijaga, 2011), 94.
} 
Tengah, pendidikan Barat dan tradisi pendidikan Islam di Indonesia. Pembaharuan tersebut meliputi tiga hal, yaitu: usaha penyempurnaan sistem pendidikan pesantren, penyesuaian dengan sistem pendidikan Barat, dan menjembatani antara sistem pendidikan tradisional pesantren dan sistem pendidikan Barat. ${ }^{12}$ Munculnya sistem pendidikan madrasah juga merupakan respon atas kebijakan dan politik pendidikan Hindia Belanda pada saat itu. Politik pendidikan Hindia Belanda membuka lebih luas kesempatan pendidikan bagi penduduk pribumi, yang sebelumnya hanya terbatas pada kaum bangsawan. Hal ini disamping merupakan politik etik, balas budi, juga merupakan salah satu usaha pemerintah Hindia Belanda untuk menundukkan masyarakat pribumi melalui jalur pendidikan. $^{13}$

Dalam bahasa yang sederhana dapat dikatakan bahwa madrasah dalam batas-batas tertentu merupakan lembaga persekolahan ala Belanda yang diberi muatan agama. Hal ini dianggap sebagai upaya perimbangan terhadap pesatnya pertumbuhan sekolah-sekolah yang memakai sistem pendidikan Barat. ${ }^{14}$ Madrasah merupakan salah satu dari Lembaga Pendidikan Islam yang ada di Indonesia; yang dimaksud Lembaga Pendidikan Islam di sini adalah lembaga pendidikan yang berbasis Islam. Pada masa lampau, banyak yang beranggapan bahwa lembaga pendidikan Islam -kompetisinya- telah kalah jauh bila dibandingkan dengan lembaga pendidikan umum, namun seiring dengan berjalannya waktu, anggapan tersebut dapat terbantah dengan kenyataan yang terjadi sekarang ini.

Latar belakang berdirinya madrasah tidak lepas dari dua faktor, yaitu; semangat pembaharuan Islam yang berasal dari Islam pusat (Timur Tengah) dan merupakan respon pendidikan terhadap kebijakan pemerintah Hindia Belanda yang mendirikan serta mengembangkan sekolah. ${ }^{15}$ Dalam konteks Indonesia, berkembangnya madrasah di Indonesia merupakan respon terhadap kebijakan politik pendidikan pemerintah Hindia Belanda.

\footnotetext{
${ }^{12}$ Karel A. Stenbrink, Pesantren, Madrasah dan Sekolah.

13 Zamakhsyari Dhofier, "K.H. Hasyim Asy’ari, Penggalang Islam Tradisional", Prisma 1, Januari 1984.

${ }^{14}$ Ensiklopedi Islam - 2.

15 Maksum, Khazanah Pendidikan Agama Islam (PT. Tiga Serangkai Nusantara, 1999), 82.
} 
Para penulis sejarah pendidikan Islam di Indonesia agaknya sepakat dalam menyebut beberapa madrasah pada periode pertumbuhan, khususnya di wilayah Sumatera dan Jawa. Mahmud Yunus memasukkan beberapa madrasah kurun waktu pertumbuhan ini antara lain: Adabiah School (1909) dan Diniah School Labai al-Yunusi (1915) di Sumatera Barat, Madrasah Nahdlatul Ulama di Jawa Timur, Madrasah Muhammadiyah di Yogyakarta, Madrasah Tasywiq Thullab di Jawa Tengah, Madrasah Persatuan Umat Islam di Jawa Barat, Madrasah Jami'atul Khair di Jakarta, Madrasah Amiriah Islamiyah di Sulawesi dan Madrasah Assulthaniyah di Kalimantan. ${ }^{16}$

Madrasah pada saat ini semakin diminati oleh masyarakat seiring dengan meningkatnya pola manajemen dan perbaikan kualitas pendidikannya. Sehingga tidak sedikit madrasah yang berhasil mencetak lulusan-lulusan yang unggul dan berkualitas di tengah masyarakat. Di Indonesia, madrasah termasuk dalam pendidikan formal yang tetap bernaung pada pemerintahan pusat. Tingkatan-tingkatan madrasah, antara lain: Madrasah Ibtidaiyah (MI), Madrasah Tsanawiyah (MTs), dan Madrasah Aliyah (MA).

Institusi madrasah merupakan sebuah lembaga pendidikan yang paling ideal dan paling sesuai dengan misi pendidikan yang dituangkan dalam amanat Undang-undang Dasar untuk menciptakan manusia yang berpendidikan dan berketuhanan Yang Maha Esa. Dikatakan demikian, karena sistem pendidikan yang diterapkan di madrasah adalah sistem integralitas, mulai dari membangun intelektual, keterampilan, moral, dan sosial. Oleh karena muatan materi yang diajarkan di madrasah adalah materi-materi yang mendukung bangunan untuk meciptakan manusia yang disamping berguna bagi masyarakat dan dirinya- yang terpenting adalah menciptakan anak didik menjadi manusia yang memiliki ketakwaan kepada Allah SWT sehingga bisa menjadi manusia berharga dalam lingkungannya.

Lembaga pendidikan madrasah dinilai memiliki kelebihan dibandingkan lembaga pendidikan konvensional, terutama pada kurikulum serta sistem pendidikan yang diterapkan. Kurikulum madrasah didedikasikan untuk membentuk karakter bangsa. Kurikulum madrasah

\footnotetext{
${ }^{16}$ Karel A. Stenbrink, Pesantren, Madrasah dan Sekolah. 
secara spesifik mengajarkan pembentukan akhlak dan moral. Secara informal, madrasah menekankan keteladanan terhadap guru sebagai sumber ilmu dan teladan. Mencuatnya resesi moral (akhlak), perkelahian, tindak anarkhis, serta berbagai tindakan menyimpang di kalangan pelajar merupakan reasoning (pemikiran/ alasan) tersendiri bagi para pelaku pendidikan untuk menghadirkan madrasah.

Akan tetapi fakta yang dihadapi dunia pendidikan saat ini adalah sebagian besar lembaga pendidikan dibangun atas dasar tujuan yang bersifat instan dan sangat praktis, hanya mengutamakan output siswa tanpa memperhatikan hal yang lebih mendasar bagi kehidupan manusia, yakni menjadi manusia yang berguna dan memiliki keagungan dalam akhlak. Ini artinya, kemasan pendidikan hanya akan dikonsumsi untuk memenuhi target lapangan kerja semata. Madrasah menawarkan bentuk sistem yang membumi dan bisa menjawab segala persoalan zaman. Tergantung pengelola sebagai pembuat kebijakan, pemerintah sebagai pemberi dukungan, guru-guru sebagai penanggung jawab di lapangan dan anak didik serta masyarakat sebagai stakeholders. Dengan demikian perlu membangun kepercayaan dan karakter optimis kepada lembaga ini, tidak melulu mencemooh, tidak harus merendahkan, tidak menganggap remeh lembaga pendidikan yang satu ini.

Madrasah merupakan salah satu lembaga pendidikan Islam yang penting di Indonesia selain pesantren. Keberadaannya begitu penting dalam menciptakan kader-kader bangsa yang berwawasan keislaman dan berjiwa nasionalisme yang tinggi. Salah satu kelebihan yang dimiliki madrasah adalah adanya integrasi ilmu umum dan ilmu agama. Madrasah juga merupakan bagian penting dari lembaga pendidikan nasional di Indonesia. Perannya begitu besar dalam menghasilkan output-output generasi penerus bangsa. Perjuangan madrasah untuk mendapatkan pengakuan ini tidak didapatkan dengan mudah. Karena sebelumnya eksistensi lembaga ini kurang diperhatikan bila dibandingkan dengan sekolah-sekolah umum yang berada di bawah naungan Kementerian Pendidikan Nasional. Kondisi yang ada sebaliknya, madrasah seolah hanya menjadi pelengkap keberadaan lembaga pendidikan nasional. ${ }^{17}$

17 http://www.scribd.com/doc/46777135/Madrasah-Dan Globalisasi, Diunduh pada 01 Oktober 2012. 
Dalam perkembangannya, madrasah yang tadinya hanya dipandang sebelah mata, secara perlahan-lahan telah berhasil mendapatkan perhatian dari masyarakat. Apresiasi ini menjadi modal besar bagi madrasah untuk memberikan yang terbaik bagi bangsa. Dalam konteks kekinian, sekarang ini banyak sekali madrasah-madrasah yang menawarkan konsep pendidikan modern. Konsep ini tidak hanya menawarkan dan memberikan pelajaran atau pendidikan agama. Akan tetapi mengadaptasi mata pelajaran umum yang diterapkan di berbagai sekolah umum. Kemajuan madrasah tidak hanya terletak pada SDM-nya saja, namun juga desain kurikulum yang lebih canggih, dan sistem manajerial yang modern. Selain itu, perkembangan kemajuan madrasah juga didukung dengan sarana infrastruktur dan fasilitas yang memadai sesuai dengan kebutuhan kegiatan belajar-mengajar di madrasah.

Dalam perkembangannya, madrasah sebagai lembaga pendidikan Islam sekarang ditempatkan sebagai pendidikan sekolah dalam sistem pendidikan nasional. Munculnya SKB 3 Menteri Tahun 1975 (Surat Keputusan Bersama Menteri Agama, Menteri Pendidikan dan Kebudayaan dan Menteri Dalam Negeri) menandakan bahwa eksistensi madrasah cukup kuat beriringan dengan sekolah umum. Munculnya SKB 3 Menteri merupakan langkah positif untuk meningkatkan mutu madrasah; baik dari status, ijazah, maupun kurikulumnya. Pada awalnya SKB 3 Menteri tersebut juga dipermasalahkan karena komposisi pendidikan umum dan agama $70 \%$ dan $30 \%$. Namun oleh Menteri Agama pada saat itu, Mukti Ali, dijelaskan bahwa dalam praktiknya kedua mata pelajaran tersebut dapat saling mengisi, sehingga sama-sama $100 \%{ }^{18}$

Sebelum SKB 3 Menteri tersebut, pemerintah telah meningkatkan penataan madrasah sebagai lembaga pendidikan formal. Penataan itu antara lain melalui Keputusan Menteri Agama No. 1 Tahun 1952, yang berisi klasifikasi dan penjenjangan pendidikan madrasah. Berdasarkan keputusan itu, pendidikan di madrasah dilaksanakan dalam tiga tingkat, yaitu tingkat dasar 6 tahun (Madrasah Ibtidaiyah), tingkat menengah

${ }^{18}$ Depag RI dan PPIM, Menteri-menteri Agama RI, Biografi Sosial Politik (Jakarta: INIS, PPIM dan Balitbang Depag, 1998).

Jurnal Pendidikan Agama Islam

Volume 01 Nomor 01 Mei 2013

Hal $188-200$ 
pertama 3 tahun (Madrasah Tsanawiyah), dan tingkat menengah atas 3 tahun (Madrasah Aliyah).

Dalam peraturan ini disebutkan juga bahwa pada ketiga tingkat madrasah tersebut minimal harus mengajarkan tiga mata pelajaran akademik yang diajarkan di sekolah umum dan mengikuti standar kurikulum Kementerian Agama. Kemudian pada tahun 1958, Kementerian Agama mengusahakan pengembangan madrasah dengan memperkenalkan model Madrasah Wajib Belajar (MWB) yang ditempuh selama delapan tahun. Pendidikan Madrasah Wajib Belajar ini memuat kurikulum terpadu antara aspek keagamaan, pengetahuan umum, dan keterampilan. Kendatipun demikian hasilnya belum optimal.

Munculnya Undang-undang Nomor 2 Tahun 1989 tentang Sistem Pendidikan Nasional, memperjelas posisi madrasah sebagai sekolah umum yang berciri khas agama Islam. Madrasah Ibtidaiyah adalah Sekolah Dasar berciri khas Islam, Madrasah Tsanawiyah adalah SLTP/SMP berciri khas Islam dan Madrasah Aliyah adalah SMU berciri khas Islam. Konsekwensi dari semua itu adalah bahwa madrasah harus memberikan materi kurikulum minimal sama dengan materi kurikulum yang ada di sekolah umum.

Madrasah yang kini sudah menjadi sekolah umum yang bercirikan Islam dengan kurikulum berjumlah 6 jam pelajaran per minggu itu belum tentu bisa membekali peserta didik memiliki pemahaman yang baik tentang Pendidikan Agama Islam kalau tidak mengaji dan melakukan kegiatan pendukung lainnya yang memadai. Dalam Undangundang Nomor 20 Tahun 2003 ada hal yang menggembirakan yaitu disamakannya madrasah dengan jenjang sekolah, tetapi kekhawatirannya juga ada yaitu berkurangnya jam-jam pelajaran terutama yang berkaitan dengan keagamaan. Sehingga tidak menutup kemungkinan ke depan lulusan madrasah belum tentu bisa membaca al-Quran dengan benar, karena mengikuti pendidikan hanya 6 jam pelajaran per minggu apalagi dengan hanya mengikuti pendidikan formal. 


\section{Eksistensi Madrasah}

Madrasah berdiri atas inisiatif dan realisasi dari pembaharuan sistem pendidikan Islam yang telah ada. Madrasah sebagai lembaga pendidikan Islam kini ditempatkan sebagai pendidikan sekolah dalam sistem pendidikan nasional. Munculnya SKB tiga menteri (Menteri Agama, Menteri Pendidikan dan Kebudayaan, dan Menteri dalam Negeri) menandakan bahwa eksistensi madrasah sudah cukup kuat beriringan dengan sekolah umum.

Di samping itu, munculnya SKB tiga menteri tersebut juga dinilai sebagai langkah positif bagi peningkatan mutu madrasah baik dari status, nilai ijazah maupun kurikulumnya. ${ }^{19}$ Di dalam salah satu diktum pertimbangan SKB tersebut disebutkan perlunya diambil langkahlangkah untuk meningkatkan mutu pendidikan pada madrasah agar lulusan dari madrasah dapat melanjutkan atau pindah ke sekolah-sekolah umum, dari sekolah tingkat dasar sampai perguruan tinggi. ${ }^{20}$

Pada tahun 1966, pemerintah mengizinkan madrasah swasta berubah statusnya menjadi madrasah negeri. Alhasil, ada 123 MI, 182 MTs, dan 42 MA yang menjadi madrasah negeri. ${ }^{21}$ Konsekuensinya, manajemen madrasah secara total bergeser dari masyarakat ke pemerintah. Meskipun demikian, sekitar 90 persen madrasah masih dikelola masyarakat setempat dengan bentuk yayasan.

Secara legal, madrasah sudah terintegrasi dalam sistem pendidikan nasional sejak diberlakukannya Undang-Undang (UU) Nomor 2 Tahun 1989 tentang Sistem Pendidikan Nasional. ${ }^{22}$ Perkembangan madrasah kemudian berlangsung cepat. Di tingkat MI, siswanya mencapai 11 persen dari total siswa tingkat dasar. Di tahun 1999, terdapat 21.454 MI dan sekitar 93,2 persennya diselenggarakan oleh pihak swasta.

\footnotetext{
${ }^{19}$ Malik Fadjar, Madrasah.

20 http://izaskia.wordpress.com/tag/kelembagaan-madrasah/, diunduh pada 18 Desember 2012.

21 Maksum, Madrasah: Sejarah dan Perkembangannya (Jakarta: Logos Wacana Ilmu, 1999), 141.

${ }^{22}$ Maksum, Madrasah: 154-155. 
Tahun 1999 terdapat 9.860 madrasah dan sekitar 88,1 persennya merupakan madrasah milik swasta. ${ }^{23}$

Secara khusus, ketentuan tentang pendidikan keagamaan dijelaskan dalam UU No. 23 tahun 2003 tentang Sisdiknas yang menegaskan: a. Pendidikan keagamaan diselenggarakan oleh Pemerintah dan/atau kelompok masyarakat dari pemeluk agama, sesuai dengan peraturan perundang-undangan. b. Pendidikan keagamaan berfungsi mempersiapkan peserta didik menjadi anggota masyarakat yang memahami dan mengamalkan nilai-nilai ajaran agamanya dan/atau menjadi ahli ilmu agama. c. Pendidikan keagamaan dapat diselenggarakan pada jalur pendidikan formal, nonformal, dan informal. d. Pendidikan keagamaan berbentuk pendidikan Diniyah, Madrasah, dan bentuk lain yang sejenis ${ }^{24}$.

Terdapat beberapa jenis madrasah, antara lain sebagai berikut: Madrasah Ibtidaiyah, Madrasah Tsanawiyah, Madrasah Aliyah, Madrasah Diniyah dan Pendidikan Guru Agama, seperti yang termaktub dalam Keputusan Menteri Agama tentang kurikulum lembaga pendidikan tersebut, yaitu: No. 74 Tahun 1976, No. 74 Tahun 1976, No. 75 Tahun 1976, No.3 Tahun 1983 dan No. 48 Tahun 1978. ${ }^{25}$

1. Madrasah Ibtidaiyah ialah lembaga pendidikan yang memberikan pendidikan dan pengajaran tingkat rendah serta menjadikan mata pelajaran Agama Islam sebagai mata pelajaran dasar yang sekurangkurangnya 30\% di samping mata pelajaran umum.

2. Madrasah Tsanawiyah ialah lembaga pendidikan yang memberikan pendidikan dan pengajaran tingkat menengah pertama dan menjadikan mata pelajaran Agama Islam sebagai mata pelajaran dasar yang sekurang-kurangnya $30 \%$ di samping mata pelajaran umum.

3. Madrasah Aliyah ialah lembaga pendidikan yang memberikan pendidikan dan pengajaran tingkat menengah atas dan menjadikan

\footnotetext{
${ }^{23}$ Asrul Nasution. Madrasah Ibtidaiyah Dalam Sistem Pendidikan Nasional "Kebijakan Dan Manajemen Pengelolaan Sekolah http://depagnias.wordpress.com /2008/03/20/menyoal-revitalisasi-madrasah-antara-peningkatan-mutu-madrasahdan-madrasah-bermutu/, diunduh pada 18 Desember 2012.

${ }^{24}$ UU No.23 Tahun 2003 tentang Sistem Pendidikan Nasional pasal 30.

${ }^{25}$ Zakiah Daradjat, dkk, Ilmu Pendidikan Islam, Cet. ke 8 (Jakarta: Bumi AksaraDepag RI, 2008), 103.
} 
mata pelajaran Agama Islam sebagai mata pelajaran dasar yang sekurang-kurangnya $30 \%$ di samping mata pelajaran umum.

4. Madrasah Diniyah ialah lembaga pendidikan dan pengajaran Agama Islam, yang berfungsi terutama untuk memenuhi hasrat orang tua agar anak-anaknya lebih banyak mendapatkan materi Pendidikan Agama Islam. Madrasah Diniyah ini terdiri dari tiga tingkat:

a. Madrasah Diniyah Awaliyah, ialah Madrasah Diniyah tingkat permulaan dengan masa belajar 4 (empat) tahun dari kelas I sampai IV dengan jumlah jam belajar sebanyak 18 jam pelajaran dalam setiap minggu.

b. Madrasah Diniyah Wustha, ialah Madrasah Diniyah tingkat menengah pertama dengan masa belajar 2 (dua) tahun dari kelas I sampai II dengan jumlah jam belajar sebanyak 18 jam pelajaran dalam seminggu.

c. Madrasah Diniyah 'Ulya, ialah Madrasah Diniyah tingkat menengah atas dengan masa belajar 2 (dua) tahun dari kelas I sampai II dengan jumlah jam belajar sebanyak 18 jam pelajaran dalam seminggu. ${ }^{26}$

5. Pendidikan Guru Agama Negeri untuk selanjutnya disingkat PGAN ialah lembaga pendidikan sebagai sambungan dari Madrasah Tsanawiyah/sederajat yang mempersiapkan siswanya untuk menjadi Guru Agama pada Sekolah Dasar, Sekolah Luar Biasa, Guru Agama/ Guru pada Madrasah Ibtidaiyah, Raudhatul Athfal/Bustanul Athfal/Taman Kanak-kanak. ${ }^{27}$

Maksud perkataan 30\% mata pelajaran agama Islam, pada Madrasah Ibtidaiyah, Tsanawiyah dan Aliyah, bukanlah ditujukan kepada isi mata pelajaran agama Islam itu sendiri, tetapi jumlah waktu yang diberikan untuk mata palajaran agama 30\% dari jumlah waktu yang tersedia di masing-masing Madrasah tersebut. Dengan kata lain, isi mata pelajaran agama tetap $100 \%$ diberikan sebagaimana yang sudah biasa dilaksanakan selama ini, hanya waktu yang disediakan untuk menyajikan

\footnotetext{
${ }^{26}$ Zakiah Daradjat, dkk, Ilmu Pendidikan Islam, 104.

27 Zuhairini, dkk., Sejarah Pendidikan Islam, Cet. III (Jakarta: Bumi AksaraDEPAG RI, 1992), 196-198.
} 
mata pelajaran agama tersebut 30\% dari jumlah keseluruhan waktu/jam pelajaran yang ada di masing-masing Madrasah tersebut.

Madrasah Ibtidaiyah, Tsanawiyah dan Aliyah terdiri dari Madrasah Negeri dan Swasta, yang lama belajarnya masing-masing 6 (enam), 3 (tiga) dan 3 (tiga) tahun dengan menggunakan sistem dan semester. Demikian pula Madrasah Diniyah dengan masa belajar seperti yang telah dikemukakan di atas. Sementara itu, Pendidikan Guru Agama Negeri memang semuanya -dewasa ini- tidak ada yang berstatus swasta, yang lama belajarnya 3 (tiga) tahun dengan menggunakan sistem semester. ${ }^{28}$

Membandingkan antara madrasah dan sekolah, jelas akan menemukan banyak perbedaan. Mulai dari input siswa, kompetensi guru dan tenaga kependidikan, kurikulum, sarana prasarana, dukungan anggaran pemerintah, dan anggapan masyarakat. Selama ini masih ada madrasah yang menerima siswa yang tidak diterima di sekolah tertentu. Apabila tidak diterima di sekolah tertentu, baru mendaftar di madrasah. Ada juga yang setelah diterima di madrasah, selama satu semester, pada semester berikutnya minta mutasi ke sekolah negeri. Dengan alasan jarak tempuh yang jauh dan lainnya. Sehingga input madrasah adalah sisa saringan sekolah.

Sementara kompetensi guru di madrasah masih belum terstandar dengan baik. Kebanyakan masih berasal dari alumni Fakultas Tarbiyah, yang diantara mereka banyak yang mengajar pelajaran selain PAI, seperti: matematika, bahasa Inggris, kertakes, bahasa Indonesia, bahasa Jawa dan lainnya. Sehingga hasilnya pun kurang maksimal. Sedangkan tenaga kependidikannya atau tenaga tata usaha masih belum memenuhi kriteria standar. Kebanyakan masih lulusan madrasah aliyah atau yang sederajat. Sehingga dalam meningkatkan kinerja mereka perlu diikutkan diklat, pelatihan yang berkaitan dengan tenaga kependidikan. Di masyarakat masih ada anggapan bahwa mutu madrasah masih di bawah standar. Input kemampuannya pas-pasan baik dari sisi latar belakang

${ }^{28}$ Zakiah Daradjat, dkk, Ilmu Pendidikan Islam, 105. 
ekonomi orang tua, nilai akademiknya atau outputnya. Sementara itu sekolah dipandang serba cukup. ${ }^{29}$

Peran dan kontribusi madrasah sejak awal kemerdekaan sangat terkait dengan peran Departemen Agama yang mulai resmi berdiri 3 Januari 1946. Lembaga inilah yang secara intensif memperjuangkan politik pendidikan Islam di Indonesia. Orientasi usaha Departemen Agama dalam bidang pendidikan Islam bertumpu pada aspirasi umat Islam agar pendidikan agama diajarkan di sekolah-sekolah, di samping pada pengembangan madrasah itu sendiri. ${ }^{30}$

Perkembangan serta kemajuan pendidikan Islam madrasah terus meningkat secara signifikan. Hal itu dapat dilihat misalnya pada pertengahan dekade 60 -an, madrasah sudah tersebar di berbagai daerah di hampir seluruh propinsi di Indonesia. Dilaporkan bahwa jumlah madrasah tingkat rendah pada masa itu sudah mencapai 13.057. dengan jumlah ini, sedikitnya 1.927 .777 telah terserap untuk mengenyam pendidikan agama. Laporan yang sama juga menyebutkan jumlah madrasah tingkat pertama (tsanawiyah) yang mencapai 776 buah dengan jumlah murid 87.932. Adapun jumlah madrasah tingkat Aliyah diperkirakan mencapai 16 madrasah dengan jumlah murid 1.881. Dengan demikian, berdasarkan laporan ini, jumlah madrasah secara keseluruhan sudah mencapai 13.849 dengan jumlah murid sebanyak 2.017.590. Perkembangan ini menunjukkan bahwa sudah sejak awal, madrasah memberikan sumbangan yang signifikan bagi proses pencerdasan dan pembinaan akhlak bangsa. ${ }^{31}$

Dalam pada itu, meskipun pemerintah melalui kementerian agama sudah banyak melakukan perubahan dan perumusan kebijakan di sana-sini untuk memajukan madrasah, namun itu belum terlalu berhasil jika dibandingkan dengan sekolah-sekolah umum yang dalam hal ini dikelola oleh kementerian pendidikan nasional. Karena realitasnya, masyarakat hingga periode 90-an masih mempunyai sense of interest yang tinggi untuk masuk ke sekolah-sekolah umum yang dinilainya

${ }^{29}$ Zainal Muttaqien, dalam www.kabar-pendidikan.blogspot.com, diunduh pada 18 Desember 2012.

${ }^{30}$ Maksum, Khazanah Pendidikan Agama Islam, 123.

${ }^{31}$ Maksum, Khazanah Pendidikan Agama Islam, 126. 
mempunyai prestise yang lebih baik daripada madrasah/ sekolah Islam (Islamic School).

Lebih dari itu, dengan masuk ke sekolah-sekolah umum, masa depan siswa akan lebih terjamin ketimbang masuk ke madrasah atau sekolah Islam. Hal itu bisa jadi disebabkan oleh image yang menggambarkan lulusan-lulusan madrasah tidak mampu bersaing dengan lulusan-lulusan dari sekolah-sekolah umum. Lulusan madrasah hanya mampu menjadi seorang guru agama atau ustdaz. Sedangkan lulusan dari sekolah umum mampu masuk ke sekolah-sekolah umum yang lebih bonafide dan mempunyai jaminan lapangan pekerjaan yang pasti.

Dalam konteks kekinian, image madrasah atau sekolah Islam telah berubah. Madrasah sekarang tidak lagi menjadi sekolah Islam yang hanya diminati oleh masyarakat kelas menengah ke bawah. Melainkan sudah diminati oleh siswa-siswa yang berasal dari masyarakat golongan kelas menengah ke atas. Hal itu disebabkan sekolah-sekolah Islam atau madrasah elit yang sejajar dengan sekolah-sekolah umum sudah banyak bermunculan. Diantara madrasah atau sekolah Islam itu adalah: Madrasah Pembangunan UIN Jakarta, Sekolah Islam al-Azhar, Sekolah Islam Insan Cendekia, Madania School, Sekolah al-Khadijah Surabaya, al-Hikmah Surabaya, MINU I Kureksari Waru Sidoarjo, dan lain sebagainya.

Sebelum mengalami perkembangan seperti sekarang ini, madrasah hanya diperuntukkan bagi kalangan masyarakat kelas menengah ke bawah. Namun sejak mulai mengadopsi sistem pendidikan modern yang berasal dari Barat sambil tetap mempertahankan yang sudah ada dan dilengkapi dengan fasilitas-fasilitas yang mendukung iklim pembelajaran siswa dan pengajaran siswa, madrasah (atau sekolah Islam) sekarang sudah sangat diminati oleh kalangan masyarakat kelas menengah ke atas. Apalagi ada madrasah yang sekarang ini sudah menjalankan praktik dengan apa yang disebut sebagai English Daily. Semua guru dan siswa dalam kegiatan belajar mengajar harus berbicara dalam bahasa Inggris.

Kemampuan bahasa asing yang bagus di era globalisasi seperti sekarang ini mutlak diperlukan. Oleh karena itu, di beberapa madrasah dan sekolah Islam itu kemudian tidak hanya memberikan pengetahuan bahasa Inggris saja. Lebih dari itu, pengetahuan bahasa asing lainnya juga diajarkan oleh madrasah, seperti bahasa Arab, atau bahasa Jepang, 
Mandarin dan lainnya pada tingkat Madrasah Aliyah. Di samping itu, dalam menghadapi era globalisasi, madrasah sebagai institusi pendidikan Islam tidak lantas cukup merasa puas atas keberhasilan yang telah dicapainya dengan memberikan pengetahuan bahasa asing kepada para siswanya dan desain kurikulum pendidikan yang kompatibel dan memang dibutuhkan oleh madrasah.

\section{E. Urgensi Madrasah di Era Kontemporer}

Masyarakat di era sekarang (kontemporer) semakin menjadikan madrasah sebagai lembaga pendidikan yang unik. Di saat ilmu pengetahuan dan teknologi berkembang pesat, di saat filsafat hidup manusia modern mengalami krisis moral dan keagamaan, dan di saat perdagangan bebas dunia makin mendekati pintu gerbangnya, keberadaan madrasah tampak makin dibutuhkan orang. ${ }^{32}$

Terlepas dari berbagai problem yang dihadapi, baik yang berasal dari dalam sistem seperti masalah manajemen, kualitas input dan kondisi sarana prasarananya, maupun dari luar sistem seperti persyaratan akreditasi yang kaku dan aturan-aturan lain yang menimbulkan kesan madrasah sebagai 'sapi perah', madrasah yang memiliki karakteristik khas yang tidak dimiliki oleh model pendidikan lainnya itu menjadi salah satu tumpuan harapan bagi manusia modern untuk mengatasi keringnya hati dari nuansa keagamaan dan menghindarkan diri dari fenomena demoralisasi dan dehumanisasi yang semakin merajalela seiring dengan kemajuan peradaban teknologi dan materi. Sebagai jembatan antara model pendidikan pesantren dan model pendidikan sekolah, madrasah menjadi sangat fleksibel diakomodasikan dalam berbagai lingkungan.

Tuntutan pengembangan madrasah akhir-akhir ini dirasa cukup tinggi. Pengembangan madrasah di pesantren yang pada umumnya berlokasi di luar kota dirasa tidak cukup memenuhi tuntutan masyarakat. Oleh karena itu banyak model pendidikan madrasah bermunculan di tengah kota, baik di kota kecil maupun di kota-kota metropolitan. Meskipun banyak madrasah yang berkembang di luar lingkungan pesantren, budaya agamanya, moral dan etika agamanya tetap menjadi

\footnotetext{
${ }^{32}$ Haedar Nashir, Agama dan Krisis Kemanusiaan Modern (Yogyakarta: Pustaka Pelajar, 1999)
} 
ciri khas sebuah lembaga pendidikan Islam tersebut. Etika pergaulan, perilaku dan performance pakaian para siswanya menjadi daya tarik tersendiri, yang menjanjikan kebahagiaan hidup dunia akhirat sebagaimana tujuan pendidikan Islam. ${ }^{33}$

Realitas menunjukkan bahwa praktik pendidikan nasional dengan kurikulum yang dibuat dan disusun sedemikian rupa bahkan telah disempurnakan berkali-kali, tidak hanya gagal menampilkan sosok manusia Indonesia dengan kepribadian utuh, bahkan membayangkan realisasinya saja terasa sulit. Pendidikan umum (non madrasah) yang menjadi anak emas pemerintah, di bawah naungan Depdiknas, telah gagal menunjukkan kemuliaan jati dirinya selama lebih dari tiga dekade. Misi pendidikan yang ingin melahirkan manusia-manusia cerdas yang menguasai kemajuan ilmu pengetahuan dan teknologi dengan kekuatan iman dan taqwa plus budi pekerti luhur, masih tetap berada pada tataran ideal yang tertulis dalam susunan cita-cita (perundang-undangan). Tampaknya hal ini merupakan salah satu indikator dimana pemerintah kemudian mengakui keberadaan madrasah sebagian dari sistem pendidikan nasional.

Pendidikan moral yang dilaksanakan melalui berbagai cara baik kurikuler (Pendidikan Nasional dan Ketahanan Nasional) maupun ko kurikuler (Penataran P-4) telah melahirkan elit politik yang tidak mampu tampil sebagai uswatun hasanah (teladan yang baik) bahkan memberikan kesan korup dan membodohi rakyat. Kegiatan penataran dan cerdas cermat P-4 (Pedoman Penghayatan dan pengamalan Pancasila) tidak lebih dari aktivitas ceremonial karakteristik. Disebut demikian karena kegiatan tersebut telah meloloskan para juara dari peserta yang paling mampu menghafal buku pedoman dan memberikan alasan pembenaran, bukan mereka yang mampu mengimplementasikan nilai-nilai Pancasila dalam kehidupan sehari-hari. Dengan demikian, para peserta penataran atau cerdas cermat P-4 berlomba-lomba menghafal butir-butir Pancasila

${ }^{33}$ Moh. Athiyah Al-Abrasyi, Dasar-dasar Pokok Pendidikan Islam (Jakarta: Bulan Bintang, 1970; lihat juga Jalaluddin dan Said, Filsafat Pendidikan Islam (Jakarta: Rajawali Press, 1996). 
tanpa berusaha melaksanakannya di dalam kehidupan nyata. Itulah di antara faktor yang mempengaruhi turunnya moralitas bangsa ini. ${ }^{34}$

Setelah kebobrokan moral dan mental merebak dan merajalela, orang baru bangun dan sadar bahwa pendidikan moral yang selama ini dilakukan lebih berorientasi pada pendidikan politik pembenaran terhadap segala pemaknaan yang lahir atas restu regim yang berkuasa. Upaya pembinaan moral yang bertujuan meningkatkan harkat dan martabat manusia sesuai dengan cita-cita nasional yang tertuang dalam perundang-undangan telah dikesampingkan dan menjadi jauh dari harapan.

Keberhasilan pendidikan secara kuantitatif didasarkan pada teori Benjamin S. Bloom (1956) yang dikenal dengan nama Taxonomy of Educational Objectives, yang mencakup tiga domain yaitu kognitif, afektif dan psikomotor. Meskipun demikian, keberhasilan output (lulusan) pendidikan selama ini hanyalah merupakan ukuran keberhasilan kognitif. Artinya, anak yang tidak pemah shalat pun, jika ia dapat mengerjakan tes PAl (Pendidikan Agama Islam) dengan baik maka ia bisa lulus (berhasil), dan jika nilainya baik, maka ia pun dapat diterima pada tingkat pendidikan yang lebih tinggi. Lain halnya dengan outcome (performance) seorang alumni madrasah, bagaimanapun nilai raport dan hasil ujiannya, moral keagamaan yang melekat pada sikap dan perilakunya akan menjadi tolok ukur bagi keberhasilan lembaga pendidikan yang menjadi tempat ia belajar. Oleh karena itu keberhasilan outcome disebut keberhasilan afektif dan psikomotorik.

Bagi lembaga pendidikan "Madrasah", kedua standar keberhasilan (output dan outcome) yang mencakup tiga domain taxonomy of educational objectives, tidak dapat dipisahkan. Di samping Madrasah mendidik kecerdasan, ia juga membina moral dan akhlak siswanya. ${ }^{35}$ Itulah nilai plus madrasah dibandingkan sekolah umum yang cenderung menekankan pembinaan kecerdasan intelek (aspek kognitif).

\footnotetext{
${ }^{34}$ Zakiah Dradjat, Membina Nilai-nilai Moral di Indonesia (Jakarta: Bulan Bintang, 1971).

${ }^{35}$ Moh. Athiyah Al-Abrasyi, Dasar-dasar Pokok Pendidikan Islam. 


\section{F. Kesimpulan}

Sebagai lembaga pendidikan yang sudah lama berkembang di Indonesia, Madrasah selain telah berhasil membina dan mengembangkan kehidupan beragama di Indonesia, juga ikut serta berperan dalam menanamkan rasa kebangsaan ke dalam jiwa rakyat Indonesia, di samping itu Madrasah juga berperan dalam mencerdaskan kehidupan bangsa. Meski demikian performa madrasah saat ini masih dirasakan berkualitas kurang dan sangat perlu untuk ditumbuh-kembangkan pada masa yang akan datang.

Bagaimanapun, masyarakat di era sekarang (kontemporer) semakin menjadikan madrasah sebagai lembaga pendidikan yang unik. Di saat ilmu pengetahuan dan teknologi berkembang pesat, di saat filsafat hidup manusia modern mengalami krisis moral dan keagamaan, dan di saat perdagangan bebas dunia makin mendekati pintu gerbangnya, keberadaan madrasah tampak makin dibutuhkan orang. Hal ini menunjukkan urgensi dan signifikansi eksistensi madrasah di era kontemporer.

\section{DAFTAR PUSTAKA}

Abd. Rachman Assegaf, Internasionalisasi Pendidikan (Yogyakarta: Gama Media, 2003).

Abdullah Idi dan Toto Suharto, Revitaslisasi Pendidikan Islam (Yogyakarta: Tiara Wacana, 2006).

Asrul Nasution. Madrasah Ibtidaiyah Dalam Sistem Pendidikan Nasional "Kebijakan Dan Manajemen Pengelolaan Sekolah http://depagnias.wordpress.com/ 2008/03/20/menyoal-revitalisasimadrasah-antara-peningkatan-mutu-madrasah-dan-madrasahbermutu/, diunduh pada 18 Desember 2012.

Depag RI dan PPIM, Menteri-menteri Agama RI, Biografi Sosial Politik (Jakarta: INIS, PPIM dan Balitbang Depag, 1998).

Ensiklopedi Islam - 2 Fas-kal (Jakarta: PT. Ichtiar Baru Van Hoeve, 1993). Haedar Nashir, Agama dan Krisis Kemanusiaan Modern (Yogyakarta: Pustaka Pelajar, 1999) 
http://www.scribd.com/doc/46777135/Madrasah-Dan Globalisasi, Diunduh pada 01 Oktober 2012.

http://izaskia.wordpress.com/tag/kelembagaan-madrasah/, diunduh pada 18 Desember 2012.

Jalaluddin dan Said, Filsafat Pendidikan Islam (Jakarta: Rajawali Press, 1996).

Karel Steenbrink, Pesantren, Madrasah dan Sekolah (Jakarta: LP3ES, 1994).

Moh. Athiyah Al-Abrasyi, Dasar-dasar Pokok Pendidikan Islam (Jakarta: Bulan Bintang, 1970).

Malik Fadjar, Madrasah dan Tantangan Modernitas (Bandung: Mizan, 1998), 19.

Maksum, Khazanah Pendidikan Agama Islam (PT. Tiga Serangkai Nusantara, 1999).

Maksum, Madrasah: Sejarah dan Perkembangannya (Jakarta: Logos Wacana Ilmu, 1999).

M. Asrori Ardiansyah, dalam www.kabar-pendidikan.blogspot.com, diunduh pada 18 Desember 2012.

Permendiknas No. 22, 23, 24 Tahun 2006.

Ramayulis, Ilmu Pendidikan Islam (Jakarta: Kalam Mulia, 1994).

Tim UIN Suka, Bunga Rampai Pendidikan Islam, Analisis Kebijakan Pendidikan Guru Madrasah Ibtidaiyah (Yogyakarta: UIN Sunan Kalijaga, 2011).

UU No.23 Tahun 2003 tentang Sistem Pendidikan Nasional pasal 30.

Zakiah Daradjat, dkk, Ilmu Pendidikan Islam, Cet. ke 8 (Jakarta: Bumi Aksara-Depag RI, 2008).

Zakiah Dradjat, Membina Nilai-nilai Moral di Indonesia (Jakarta: Bulan Bintang, 1971).

Zuhairini, dkk., Sejarah Pendidikan Islam, Cet. III (Jakarta: Bumi AksaraDEPAG RI, 1992).

Zamakhsyari Dhofier, “K.H. Hasyim Asy’ari, Penggalang Islam Tradisional", Prisma 1, Januari 1984.

Zainal Muttaqien, dalam www.kabar-pendidikan.blogspot.com, diunduh pada 18 Desember 2012. 